This item was submitted to Loughborough's Research Repository by the author.

Items in Figshare are protected by copyright, with all rights reserved, unless otherwise indicated.

\title{
'Heroes into zeroes'? The politics of (not) teaching England's imperial past
}

\section{PLEASE CITE THE PUBLISHED VERSION}

http://dx.doi.org/10.1080/03086534.2014.959718

\section{PUBLISHER}

(c) Taylor \& Francis

\section{VERSION}

AM (Accepted Manuscript)

\section{PUBLISHER STATEMENT}

This work is made available according to the conditions of the Creative Commons Attribution-NonCommercialNoDerivatives 4.0 International (CC BY-NC-ND 4.0) licence. Full details of this licence are available at: https://creativecommons.org/licenses/by-nc-nd/4.0/

\section{LICENCE}

CC BY-NC-ND 4.0

\section{REPOSITORY RECORD}

Yeandle, Peter. 2019. "'heroes into Zeroes'? the Politics of (not) Teaching England's Imperial Past". figshare. https://hdl.handle.net/2134/25606. 


\section{“Heroes into Zeroes”? The politics of (not) teaching England's imperial past.}

Peter Yeandle

This article revisits the fiercely contested national curriculum history debates of the 1980s and 1990s. Although these debates have been subject to intense academic scrutiny, from educationists and historians alike, too little attention has been paid to the various assumptions about the inclusion (or exclusion) of hero figures in the curriculum. The article situates debate about heroes both in the context of late twentieth century educational reform, but also wider historiographical analyses of Britain's (or, better put, England's) perceptions of itself as a post-imperial power. In the battle to define the content of school history, certain commentators invoked hero figures to help press their cause. What becomes clear from analysis of media intervention, however, is an ambiguity about the place and cultural/political purpose of specifically 'imperial' heroes. This ambiguity, I argue, reflects contemporary unease about how to confront the imperial past.

History teaching has been captured by those who have no admiration of the past of their own country and see it as little more than a tale of imperialism abroad and oppression at home. Small wonder, then, that so many young people appear to have no love of their country, and so many are virtually strangers in their own land, mistrustful of its institutions and contemptuous of its heroes and leaders. We have a generation who are not just ignorant of their history, their literature and their religion, but who care nothing for any of it (Daily Mail, 18 April, 1995).

In common with other contributions to this themed issue, this article analyses the cultural afterlives of imperial heroes in order to investigate the politics of imperial memory. My focus, specifically, is on the fiercely-conducted public debates between the 1980s and early 2000s about the teaching of history in English schools. The National Curriculum [NC], set in motion following the Education Reform Act of 1988, was finally implemented in 1991 - yet debates about the purpose of the teaching of history both preceded and post-dated these key 
years. These debates were about the first national curriculum in English educational history; thus, the NC constituted the first time that the state would prescribe historical content and teaching methodology. ${ }^{1}$ NC debates are of particular significance for a study of the cultural afterlives of heroes since they provide a useful means to consider the role of the state in framing an 'official', as opposed to an unofficial, memory of the national past. This is an important distinction. In a context in which 'History' was increasingly fragmented into consumerist histories, ${ }^{2}$ whether through the increasing scope of film and television to serve as an interpretative lens on the past (as Max Jones' essay highlights) or as a result of the uses of imperial history or practices by former colony (as seen in Berny Sèbe’s and Robert Bickers' articles), the 'battle' to shape NC history operated as a contest to control a state-sanctioned account of the national past. What purpose, specifically, was attributed to heroes? What does their inclusion, or exclusion, from the curriculum indicate about the relationship between official history and identity? Does their treatment reveal clues about the politics of imperial memory?

Use of the word 'battle' is not hyperbolic. ${ }^{3}$ The formulation and implementation of the NC led on to furious debate across the late 1980s and 1990s - what one group of educational researchers in 1993 described as 'nothing less than a public and vibrant debate about the national soul'. ${ }^{4}$ Militaristic words were invoked in media reporting: the Express described Thatcher's 'conquest' of schools (4 April 1990). But 'battle’ was by far the most common. Robert Skidelsky wrote of the 'Battle for Britain's Past Times' in the Independent (22 August 1989). Martin Kettle, writing for the Guardian at the height of these disputes, described their significance in an article entitled ‘The Great Battle of History’: 'Margaret Thatcher has fought many historic battles for what she sees as Britain's future', yet 'few of them are as pregnant with meaning as her current battle for control over Britain’s own history ... If the Prime Minister can change the way that we are taught history, she will have succeeded in changing the ground rules for a generation to come. It is a big prize' (4 January 1990). A considerable number of studies, especially those written by educationists, located debates about NC History within wider analyses of the relationship between history teaching 
and national identity. ${ }^{5}$ Given that the NC was to relate to English and Welsh schools, the debate took on added significance in the context of scholarly intervention into Anglo-British identity-relations. ${ }^{6}$ The importance of NC debates, moreover, is attested to by the expansive list of references to them in Hansard, the extent to which they have been 'remembered' in the memoirs of key political figures and the way in which they became a 'case-study' in political analyses of the Thatcher years. ${ }^{7}$ The 'great history debate' was referenced in the 1990s in studies exploring the relationship between education and the state, ${ }^{8}$ as well as its contributions towards children's perception of Europe and European integration. ${ }^{9}$ It is no surprise that these debates have been visited by historians offering broad analyses of the relationship between history and identity: see, for instance, Peter Mandler's work on public history and Joanna de Groot's brief comments in her recent analysis of empire in the writing of history. ${ }^{10}$

Yet few historians have investigated the significance of the statutory inclusion, or exclusion, of heroes in the $\mathrm{NC} ;{ }^{11}$ a curious omission given the rich historiography of the study of heroes explored in this issue's introduction. This oversight includes David Cannadine, Jenny Keating and Nicola Sheldon’s history of twentieth-century history teaching, The Right Kind of History (2011), which sought - in part - to situate debate about contemporary reforms to history teaching in historical context. ${ }^{12}$ Heroes played a central role in debates, recruited by cultural critics in their battle to define nation and identity. Most obviously, they were used to illustrate newspaper articles - Kettle's essay, for instance, is illustrated by a half-page reproduction of a painting of the Death of Nelson (attributed to Corbould). Their presence, however, was more than mere decoration. The visual presence of key English figures emphasised that their potential exclusion posed a threat to the fabric of national history; they embodied a usable nostalgia in which critics of new approaches to the teaching of history - who had been building up a head up steam across the 1980s - could communicate their wish for the restoration of a 'traditional' curriculum. Heroes were used to embody the notion of loss; the loss of a golden age of history teaching in particular and the loss of curriculum which promoted patriotism in general. In May 1994, in response to a 
sense that insufficient British history had been included in a revised NC, the Star declared 'British heroes set to become History' (5 May 1994). Gary Bushell, in the Sun, beseeched the government not to 'let teachers turn our heroes into zeroes' (20 Sept. 1995). This special issue, then, gives me the opportunity to redress the surprising lack of scholarly analysis of the role of the hero in NC debates. My findings suggest that both the noise and silence in the treatment of heroes in last two decades of the twentieth century provide a useful means to assess the ambiguities of Britain as a post-imperial nation.

This article is organised into four sections. First, I outline alterations to the teaching of history in the 1970s and '80s. In this period, advances in educational psychology became manifest in teaching practice. The highly influential so-called 'new history' sought both to privilege the teaching of skills over chronologically-arranged factual content and make history relevant to the average schoolchild. 'Relevance' comprised a conscious move away from teaching narrowly English political history by providing increased attention to world history. This included the insertion of individuals from minority groups into teaching programmes, both those whose lives were intimately bound up with British history (such as Olaudah Equiano and Ghandi) and those from overseas (most prominently, Martin Luther King). The period also witnessed the creation of multiple resources for the teaching of heroines: Elizabeth Fry, Florence Nightingale, Mary Seacole, to name but a few. Such a dramatic shift in content and teaching methodology led to significant backlash, as analysed in Section II, in particular from New Right pamphleteers and right-wing journalists. The third section analyses the debates both about the formation of a national curriculum in 1989/90 and subsequent reforms to the curriculum up to 1995. In particular, I argue that the press took on a significant role by framing the debate as a series of binary opposites: patriotism versus antipatriotism, factual content versus skills/pedagogy, traditional versus newfangled. It was in this context that NC history became understood as the official national narrative and that the 
selection and omission of heroes, as key individuals who shaped that history, took on added significance.

The demand, by the New Right, for more teaching of the national past was at odds with a reluctance publicly to engage British imperial history, a paradox symptomatic of Britain's post-imperial identity crisis. ${ }^{13}$ Given that questions over race and imperial memory were central to these debates, though not always explicitly articulated, the final section uses responses to the Parekh Report, The Future of Multi-Ethnic Britain (2000) to analyse the extent to which disputes over the teaching of history can be understood, in Anne-Marie Fortier's words, as a 'politics of reckoning with the imperial past' ${ }^{14}$ In order to address issues of race-relations, the Report recommended an overhaul of the teaching of history. It was met with vitriol in the press, leading Jack Straw (the then Labour Home Secretary) to distance himself from its conclusions. My argument is that one can identify a continuity of criticism from the political right, from the 1980s into the 2000s, in which the request for more national history is put forward as a core ingredient of identity. Suggestions to rewrite national history - which included the perceived belittling or omission of key heroes - was seen to be testament to denigrating the nation. Yet, specifically imperial heroes are noticeable for their absence in this proposed pantheon: they were too controversial for inclusion in a curriculum that sought to promote unquestioned national greatness. The imperial past, and the end of Empire, was skirted in the 1980s and '90s, but confronted head on by the Parekh Report. The Report - in calling for 'a rewritten history of Britain as an imperial force' necessitated an engagement with the imperial past in consideration of the relationship between history teaching and national identity. ${ }^{15}$ Thus, analysis of those heroes included and excluded in debates about the teaching of history enables engagement with questions about the relationship between the imperial past and post-imperial ambiguities of identity.

\section{I - Context: the 'new' history and the making of the NC, 1968-1989.}


Kettle's essay (cited above) was written in January 1990 in response to the completion of the History Working Group’s Final Report. January 1990 was one of a series of media flashpoints in which the battle over school history reached fever pitch. Other key dates included: the formation of the Working Group in January 1989, and the publication of its Interim and Final Reports (August 1989 and April 1990); response to the Dearing Report (July and December 1993); the publication of draft proposals, based on Dearing, for an amended curriculum (May 1994); the eventual writing of amendments into statute (January 1995); and the attacks on the NC as ahistorical and unpatriotic by the then Chair of the Qualifications and Curriculum Assessment Authority [QCAA], Nick Tate, in September 1995. These dates, quantified in the findings of an ESRC-sponsored project entitled 'British Island Stories: History, Identity and Nationhood', witnessed significant surges in media reporting. ${ }^{16}$ As part of the project, a database was compiled which documented all references in the mainstream press to the teaching of history between 1989 and 1995. It has been possible, as a result, to analyse these newspapers in order to quantify which heroes were most discussed: Nelson, Alfred, Nightingale, Wellington, and Churchill formed the canon of desirable heroes with few others mentioned. Those involved in the discovery, conquest and maintenance of colonies were noticeable for their relative absence: Clive and Wolfe each get one mention, Captain Cook and Livingstone two. There were no calls in the press for the compulsory reinstatement of Gordon, Havelock, Napier, Roberts, Kitchener, indicative of ambiguities about the usability of imperial past. Prior to analysis of NC reforms, and response to them, it is important to highlight changes in the teaching of history in the 1970s and '80s; especially so since the NC incorporated aspects of the 'new' history and it was as much the persistence of pedagogical innovation, as content, that was subject to consternation.

'New' history sought to make the teaching of history relevant to modern Britain and did so in light of research in the 1960s and early '70s which suggested not only that history had become unpopular with young people but that further disinterest would lead to its curricular extinction (analogy was drawn to the fate of Latin in comprehensive schools). ${ }^{17}$ It also sought to teach a present-oriented curriculum which aimed to enable children an 
understanding of the modern world. New history would not only shake up the content of school history but also its methodology. In 1968, Mary Price published an essay - 'History in Danger', in the journal History - which, based on quantitative research with children and teachers, was to have a transformative impact. Price's express concern was that the persistence of traditional content and teaching methods - identified as uninspiring teaching, rote-learning, and examination - needed urgent remedy. ${ }^{18}$ Response was rapid: by 1969, the Historical Association had developed its own educational wing and in-house magazine, Teaching History; ${ }^{19}$ by 1972, the Schools Council History Project [SCHP - dropping the C in 1984] had formed; ${ }^{20}$ and by 1976 the Council had published its pioneering A New Look at History, a text which would go on to exercise a profound impact on historical education in the 1980s. ${ }^{21}$ Drawing from cutting-edge educational psychology, in particular the work of Jean Piaget, Jerome Bruner and Benjamin Bloom, ${ }^{22}$ SHP generated new syllabi for schools and recommended new teaching methodologies. ${ }^{23}$ 'Traditional' emphasis on assessment by memorisation was replaced by a series of innovative tasks encouraging children to think critically about primary sources and understand history as interpretative. ${ }^{24}$ Although official syllabi were not taken up by all schools, ${ }^{25}$ new history enshrined the concept of 'relevance' and exercised a considerable influence on the teaching of history in general. ${ }^{26}$ John Slater, at the time the government's Chief Subject Inspector for History in English schools, summarised their 'earthquake’ effect in 1986:

While there has been a sea, and sometimes stormy, change in the content of history syllabuses, there has been an earthquake in the methodology, pedagogy and above all, in the learning of history by young people in schools. Pupils are now being asked to evaluate source material critically. They are asked to enter into a degree of understanding of the attitudes and predicaments of people who are different from them, because they lived a long time ago, or were poor, or rich, or had a different colour, or religion, or sex, or aspirations. They discover that historical statements are ultimately not concerned with the transference of agreed facts but are nearer to the making of informed judgement. They are appreciating that such statements are often 
tentative and provisional and that contrasting and equally valid conclusions may be drawn from the same evidence. ${ }^{27}$

It was also understood that the content of lessons required alteration. In 1970, the educational theorist Martin Ballard argued, for its very survival as a discrete school subject, classroom history needed to 'break out of the narrow nationalistic straitjacket in which it had lived for so long'. ${ }^{28}$ Advocates of new history sought to use history not only to teach essential skills, but to distance the teaching of British history from the 'teleological optimism' of 'traditional' anglocentric high-political history. ${ }^{29}$ In order to make history relevant, the aim was to give minorities and others excluded from the traditional curriculum historical voice: not just ethnic minorities, but women, the workers and the poor. ${ }^{30}$ A number of surveys had highlighted the endurance of content formulated in the early twentieth century. In the late 1950s, C.F. Strong warned that 'current conceptions of history teaching have evolved in a period of less than a century. It is perhaps not surprising, therefore, that in no short time, the material and method of that teaching should have remained substantially what they were in the early days of their development in the last quarter of the nineteenth century'. ${ }^{31}$ Maureen Bryant, in her Report of the History Syllabus Conference of 1967, stated: 'No-one in this country would advocate a prescribed course and yet there is a great deal of uniformity. Pressures from tradition - our own school days, courses at older universities, the whole apparatus of textbooks and examination syllabuses which we have inherited, all tend to produce uniformity'. ${ }^{32}$ In Slater's parody, the traditional approach privileged British political history and was taught through rote learning:

Content was largely British, or rather Southern English; Celts looked in to starve, emigrate or rebel; the North to invent looms or work in mills; abroad was of interest once it was part of the Empire; foreigners were either, sensibly, allies, or rightly, defeated. Skills - did we even use the word? - were mainly those of recalling accepted facts about famous dead Englishmen, and communicated in a very eccentric 
literary form, the examination length essay. It was inherited consensus, based on largely hidden assumptions [my italics]. ${ }^{33}$

Advocates of new history sought, therefore, to make history meaningful to all British children in the modern world: famous dead Englishmen were to remain, but new content would witness the introduction of new historical actors - some of whom could be labelled 'heroes' into history teaching. Moreover, new history encouraged children to ask critical questions about individuals: it would not be uncommon to find a lesson asking children to investigate why Clive was made heroic, but Guy Fawkes a villain. As will be seen in the next section, when critics of new history demanded the restoration of past practice it was precisely the 'traditional' system they wanted reinstated.

The SHP syllabus was organised into four approaches, or categories of historical understanding, each geared towards advancing children’s skills of critical enquiry and also encouraging them to question present-day issues: 'Study of Development', 'Enquiry in Depth', 'Studies in Modern World History' and 'History around Us'. 'Study of Development' was intended to teach chronology and change over time. The most popular 'Development' module was 'Medicine through Time’ which witnessed the entrance of Lister, Jenner and other medical innovators into the curriculum (no mention, noticeably, of the characters Bertrand Taithe analyses in his article featuring heroes of medicine); it also incorporated Florence Nightingale and Mary Seacole. Other 'Development' modules included focus on the changing role of women in British society (enter: Elizabeth Fry, Octavia Hill, Millicent Garrett Fawcett, and the Pankhursts) and 'Crime and Punishment' (which did not so much entertain new 'heroes' per se, but introduced children to topics such as the Peterloo Massacre, Chartism, the Tolpuddle Martyrs and the General Strike as well as witchcraft, the development of the police force and the modern prison system). 'Enquiry in Depth' encouraged the 'imaginative reconstruction' of the past through 'contrast with the present'. Example modules included Elizabethan England and the American West. 'Studies in Modern World History’ sought to help children understand contemporary issues through historical 
contextualisation: modules initially included modern China, the European Union, and the Arab-Israeli conflict; later, India (Ghandi), apartheid (Mandela) and American civil rights (Martin Luther King) became options. A module on decolonisation was proposed, but not taken up, even though the original Project suggested children should study 'New African Nations'. Finally, 'History around Us' encouraged field trips and the handling of artefacts and was to be delivered through tracing local history through time. Encouragement was placed on local 'heroes' and understanding the past motivations of historical ancestors, whether the documented 'factory owner' or nameless hundreds of local 'factory workers'. ${ }^{34}$

\section{II - Reactions and Response}

The new history, therefore, introduced a new cast of characters into the teaching of history. It also introduced new pedagogies of learning and teaching which emphasised critical enquiry. It is not surprising that many on the political right found these modules worrying. Their criticisms of the new history can be traced across the 1970s and '80s, first in a series of Black Papers, and then in pamphlets published by think tanks. ${ }^{35}$ By the late ' 80 s and the time of debate specifically about a national curriculum, critics had established a discourse of usable history that was to typify newspaper articles. ${ }^{36}$ For them, History’s prime purpose was to instil national pride. In their view, new history not only undermined this objective but deliberately subverted it: history needed to be rescued from the educationists since they were intent to teach leftist criticisms of the national past which, as a consequence, equated to a deliberate attack on the national present. For those antipathetic to 'new' history, it became a mission to influence the NC: state-prescribed history lessons had to privilege continuous national history, reinforce the teaching of knowledge through the incorporation of rigorous assessment structures, and - crucially - by teaching incontrovertible facts, serve as a site for the transfer of cultural identity.

Thatcherism was crucial to the escalation of the history debate because it gave voice and a sense of unity to 'the ideology' of the 'New' conservative Right. The New Right was a 
disparate group: not all who associated themselves with the New Right contributed to the rightist attack on 'new' history. I use the term in the singular, however, as a means to refer to those interested in the role of schooling with regards to the transmission of cultural values rather than those primarily interested in the economic aspects of the debate over schooling. Indeed, despite the contradictions of the neo-liberal and neo-conservative values that constituted the New Right's ideology, they were nonetheless a political grouping highly influential in the shaping of the 'great history debate'. Frequently they held influence in conservative think-tanks and occasionally had the ear of ministers. ${ }^{37}$ Neo-liberalism, on the one hand, was essentially an economic doctrine rooted in the thinking of Hayek: it was critical of socialism, promoted non-intervention in the economy and the freedom for the forces of the market to resolve issues of social policy - including education policy. Central to the neo-conservative stance, in contrast, was strong paternalistic government promoting disciplined society, social authoritarianism, hierarchy and subordination. It was thus that Gamble commented that ingrained in Thatcherism was the inconsistency that to 'preserve a free society and a free economy, the authority of the state had to be enforced' ${ }^{38}$

New Right animosity towards pedagogical innovations to the teaching of history can be traced in a number of pamphlets published by think tanks in the run up to 1989, as well as interventions in the press. Most echoed statements made by Mrs Thatcher in a speech to the Conservative Party conference in 1975: 'We are witnessing a deliberate attack [...] on our heritage and our past, and there are those who gnaw away at our national self-respect, rewriting British history as centuries of unrelieved doom, oppression and failure — as days of hopelessness, not days of hope'. ${ }^{39}$ The 'new' history was, according to Stuart Deuchar, a 'wilfully perverse dismissal of historical content and facts' by left-wing 'experts' which had precipitated 'a fundamental loss of faith in our civilisation' ${ }^{40}$ History should be used to foster in the young a sense of belonging to the nation, added Geoffrey Partington (writing for the Social Affairs Unit), because there 'is a pride or reverence in our national past' that needs celebrating not undermining. Advocates of new history, in his opinion, were 'a host of irrational and malignant sprites' who sought to undermine British 'heritage and tradition'. ${ }^{41}$ 
Robert Skidelsky, though not himself strictly part of the New Right, echoed their sentiment: 'new history', he feared, was the manifestation of a left-wing plot to erode national identity: a ‘subversive history curriculum’ had been ‘socially engineered’ by left-wing academics (Independent, 1 March 1988). 'New history’ modules were labelled by their critics as a 'Shop Steward Syllabus', conducted by a 'Friendly Red Army’ of teachers accused of 'peddling crackpot ideologies' and 'leaving our young people distrustful and confused'. ${ }^{42}$ These are hardly surprising critiques given that the selection of content in the SHP syllabuses both reflected the 1960s' emergence of social history as a discipline and the 1970s trend towards 'world studies'. ${ }^{43}$ Little wonder the political right baulked at the prospect of children studying histories of protest, working conditions, women's history and comparative global history; each of these alone threatened to teach children about the shadowy aspects of the British past; taken together SHP programmes were seen to constitute a leftist assault on traditional history and culture. Helen Kedourie, in her contribution for the Centre for Policy Studies [CPS] - The Errors and Evils of the New History - added that new history was a disgrace since it 'elevated world history above our own' which was 'so rich and varied' ${ }^{44}$ Kedourie took an axe to 'history from below' in particular, arguing that it denied children access to the 'the richness of history ... to belittle the role of those labelled as great is to take a partisan and impoverished approach to history'. ${ }^{45}$ Such critique would inform press response to the publication of the NC. New Right language was also evident in political intervention. It was within this context that debates about the teaching of heroes is so illuminating: the teaching of unconventional historical figures, it will be seen, was likened to the belittling of traditional heroes.

The trend towards teaching non-British history, or non-'traditional' history, had been recognised by the State before the NC History Working Group was formed in 1989. In its advice of 1988, the Department of Education and Skills suggested 'History courses should nowadays pay greater attention than was formerly the case to the position of minority groups and the role of women in history' ${ }^{46}$ Although this was somewhat tokenistic, and included no official recommendations (nor did the advice recommend specific historical characters), it 
nonetheless reflected changes to historical education and demonstrated the understanding that British history could not narrowly be taught by resort to the anglocentric narrative. This was evident when the final curriculum was published after a painstaking process of debate, several rewrites, and political intervention. When the NC for state Secondary schools finally emerged, it was a compromise document blending pedagogical techniques retained from the SHP but prioritising British history. In Raphael Samuel's words, it found itself 'facing both ways'. ${ }^{47}$ Most debate related to the Secondary school curriculum, though - as seen below there was a conflation of Primary and Secondary school prescriptions in media response. The NC would be organised around core units in mostly British history, arranged chronologically, spanning from: 'The Roman Empire’, 'Medieval Realms' (1066-1500); 'The Making of the United Kingdom’ (1500-1750); and ‘Expansion, Trade and Industry’ (1750-1900); culminating in a fifth core module 'The Era of the Second World War'. The curriculum was to be completed by the school's choice of modules from two broad categories: 'an Episode or Turning Point in European History from before 1900' (popular modules included the Crusades and the French Revolution); and a past non-European society (options included Indian, Chinese and American history). Primary school units included coverage of 'Invaders and Settlers' (Romans, Saxons and Vikings); Tudors and Stuarts; the choice of 'Victorian Britain’ or 'Britain since 1930’; Ancient Greece; the Voyages of Exploration; and a study of a non-European society (Aztecs, Benin, Ancient Egypt, Indus Valley). Much of the methodology of 'new' history remained, however, and became written into statute as attainment targets. Not only were children to accumulate knowledge, they were also to learn about bias through the study of primary sources. Crucially for educationists, and to the dismay of critics, no definitive list of compulsory 'facts' would 'be drawn up for testing purposes that did not imply a particular interpretation'. ${ }^{48}$

Thus, the curriculum resisted pressure only to only teach British history by including a broad sweep of British, European and world history. At secondary level it was chronologically arranged and privileged national history. Despite this, the final NC document met with serious criticism in the press and was subject to political intervention, 
including from the Prime Minister herself. It is to the analysis of these criticisms of the curriculum - and the role of heroes within debate - that I now turn.

\section{III - Defining the heroic in a national curriculum for history, 1989-1995.}

Much of the debate about the NC related to the political appropriateness of the Conservative government's explicit intention to use the classroom to inculcate patriotism. There was some minor dispute between Conservatives about state prescription, yet consensus prevailed about the requirement to teach chronological national history. ${ }^{49}$ Jack Straw, then Shadow Secretary of State for Education, accused the Prime Minister in Parliament of turning the 'history syllabus into no more than a vehicle for the jingoistic, right-wing indoctrination of our children' ${ }^{50}$ There can be little doubt, as analysis below demonstrates, that these debates were about the definition of patriotism. I will return to the questions of political alignment below, especially the alternative canon of heroes suggested by left-wing academics in counterpoint to the overconcentration in the media on the use of heroes to impart national pride.

Analysis of the media treatment of heroes suggests they were inscribed with a particular patriotic purpose and that their inclusion/exclusion was debated largely around issues of patriotism and identity. Certain heroes were selected specifically because they were usable in the context of late twentieth-century England; others - those who had been core actors in the formation of the heroic myth of empire - Gordon, Havelock, Lawrence - were omitted. As will be seen, the majority of the media critique corresponded to Conservative political will: this was, in part, the exhibition of those populist strategies linking the state to patriotism, through the rhetoric of nationhood, that Stuart Hall and others detected in the 1980s. ${ }^{51}$ When Thatcher convened the HWG to formulate a NC for history, she did so with two explicit intentions. First, as she recalled in the Downing Street Years, she 'distrusted the new “child-centred” learning techniques ... [and] believed that too many teachers were less

competent and more ideological than their predecessors'. ${ }^{52}$ She wished to return the teaching of history to a straightforward content-led narrative by reversing changes brought about by 
the application of developments in educational psychology. Second, since new history encouraged an enquiring approach to past characters and events, as well as attempts to understand past motivations, hero figures - and the factual certainties about them - needed to be reclaimed for the nation (children certainly should not try to understand their motivations or, worse, their feelings, as had been required by SHP). Disdain for such an approach is evident in Thatcher's own words: History

is an account of what happened in the past. Learning history, therefore, requires knowledge of events ... a clear chronological framework - which means knowing dates. No amount of imaginative sympathy for historical characters or situations can be a substitute for the initially tedious but ultimately rewarding business of memorising what actually happened. ${ }^{53}$

Heroes should be known in a way that meant their heroism in the national cause could be taken for granted. There was no space in this formula for a critical approach to heroes (an irony explored in the next section of this article).

That the proposed NC failed to include sufficient national history led to serious condemnation in the press. 'The country that forgets its own history is dead from the neck up', Keith Waterhouse waxed in the Daily Mail in response to the NC Interim Report, continuing: 'all the evidence is that as a nation we are suffering from a creeping amnesia when it comes to our collective past’ (21 August 1989). That insufficiency was accentuated by the absence of a compulsory place for heroes on the curriculum. Two days before the publication of the Final Report, the Sunday Telegraph (1 April 1990) reprinted a question raised by John Stokes (Cons) in Parliament during Prime Minister’s Questions:

Sir John Stokes: Is my right hon. Friend aware that there is considerable anxiety about the teaching of English history in our schools? Instead of teaching only what are called themes, why cannot we go back to the good old days when we learnt by heart 
the names of the kings and queens of England, the names of our warriors and battles and the glorious deeds of our past? [Interruption.]

Mr. Speaker: Order. I am sure that the whole House wants to hear the reply.

The Prime Minister (Thatcher): As usual, my hon. Friend is absolutely right. What children should be taught in history is the subject of vigorous debate. I agree with him. Most of us are expected to learn from the experience of history and we cannot do that unless we know it. Children should know the great landmarks of British history and should be taught them at school. ${ }^{54}$

Stokes' idealisation of history was precisely the stuff of narrative political history that the SCHP had sought to alter: note the suggestion that rote learning should be reinstated, that the 'good old days' included knowledge of keynote individuals and their 'glorious deeds'. Stokes' wish was indicative of the mobilisation of school history as usable nostalgia; the absence of heroes connoting an absence of patriotism.

The battle to define the precise content of the curriculum remained unresolved. NC History was first taught in 1991 but it found itself immediately under challenge. New Right critics remained incensed at the perceived lack of British history, including heroes. It is no surprise, then, that another committee was formed to review the history curriculum and to suggest changes - including how to put the teaching of history into a national frame. Lessons had been learnt that the NC was too densely packed. The Dearing Committee, appointed to streamline the curriculum, found itself subject to the same pressures as the HWJ. Media critique was to surface again in May 1994 in anticipation of the publication of Dearing's review. Once again, heroes took centre stage in the articulation of a curriculum perceived to be incomplete. Committee member Chris McGovern had grown dissatisfied with the direction of Dearing's review group so published his own 'minority' report, via the New Right pressure group, the Campaign for Real Education, in advance of the publication of the Dearing Report. ${ }^{55}$ The media latched onto McGovern's misgivings that there was insufficient national history, that too much non-British history was taught, and that heroes - in particular 
Nelson, Florence Nightingale, Queen Victoria and Winston Churchill - had still not been made official constituents of a now state-prescribed curriculum. The Telegraph (5 May 1994), took up McGovern's mantle: 'We are a great civilisation, the mother of others throughout the English speaking world, and a wellspring of the highest achievements in the practice of government, law, trade, industry, and the life of the mind, the sense and the spirit. We traduce Britain’s glory if we teach a history which makes us seem just like anybody else'. Here, heroes served to distinguish the English past from other national histories and embodied core English values. In an article entitled 'Battle of Britons', Today claimed that the 'great events and figures from British history could disappear' (5 May 1994). The Star lamented 'British heroes set to become history' (5 May 1994) and the Sun announced ‘Britain’s glorious past banished from lessons’ (5 May 1994).

The Englishness of ideal heroes was emphasised by denigration of what was included in the curriculum. The Today article carried the strap-line 'Aztecs take over from Nelson in history class' and claimed that 'the Battle of Agincourt will be replaced by everyday life in Benin'. This was a clear confusion of primary and secondary curricula: it is difficult to think this was anything other than a deliberately alarmist distinction drawn for journalistic effect: by posing Beninese history as the replacement, the loss of English heroes was accentuated and the implication was that the new history was anti-patriotic. The Sun article continued (emphases in original): 'OUT' go Henry VIII, Churchill, Guy Fawkes and Nelson but 'IN' comes the 'struggles of Namibian women'. Readers were invited to take part in a telephone poll to answer the (rhetorical) question ‘should our children be taught about Britain's heritage, or should Nelson and Waterloo be taken off the curriculum? If you think we should stick to traditional history, ring...' To help readers decide, the author informed them that the alternative to teaching 'the role of great men and women, the origins of Parliament, the rise and fall of the empire and the development of democracy' was compulsory lessons in 'popular protest' taught through 'sociological, ethnic and gender perspectives'. Expanding McGovern's list of crucial heroes, readers were invited to choose between Alfred the Great, Nelson, Blenheim, Marlborough, Clive, Wolfe, Wellington and Nightingale on the one hand, 
or Islamic Civilisations, the Indus Valley, and the Aztecs on the other. The report was encircled with images of key heroes and in a particularly blatant exercise of visual othering, Nelson was situated next to a photograph of half-naked Namibian women and their mud huts. The Express, similarly, accentuated the omission of Nelson by noting what was to be the statutory inclusion of Islamic Civilisations and Black Peoples of the Americas instead (5 May 1994). Given this formulation, it is possible to offer one explanation for the relative absence of heroes from the imperial canon: if the aim was to celebrate national greatness by making disdainful judgements on the importance of Asian and African histories, then it would be too contentious to include in the wish list of English heroes characters central to colonial subjugation of those continents. Indeed, to teach Gordon and Havelock would require confronting the imperial past, a proposition too problematic in the context of the time. I will return to this question in the next section.

A year later, Nick Tate, Chief Executive of the Schools Curriculum and Assessment Authority delivered a series of speeches about how history education was inadequate. He bemoaned that, in the face of rapid social change, children were no longer made aware of their heritage as a means to help them understand their identity. ${ }^{56}$ In particular, Tate urged increased exposure to national heroes in the classroom: his preferred characters included Wolfe, Nelson, Livingstone, Shaftesbury, Victoria and Nightingale (Sun, 19 July 1995). ${ }^{57}$ Gary Bushell, in the Sun, awarded Tate 'top marks' and beseeched the government not to 'let teachers turn our heroes into zeroes’. He continued: ‘children aren’t taught about the great men and women who shaped our island anymore ... The notion of great achievers doesn't fit the quasi-Marxist views of today’s education "experts”' (20 Sept. 1995). ${ }^{58}$ Nelson was uncomplicated: he could be cast as a national hero, not an icon of imperialism. His heroism was on the sea, against the French. The Sun (5 May 1994) lamented that his story had become reduced to 'pictures and maps'. Instead, it wanted emphasis on his 'bravery' and celebration that he 'had a tremendous impact on our history'. There was never any need, as Raphael Samuel pointed out, to engage the question of why Nelson was a hero. The desire to include stories of Nelson's naval victory makes sense in the context of contemporary fears about 
European integration. The Maastricht Treaty had been signed in 1992, membership of the European Union enlarged in 1994, and the Euro currency set to be launched in late 1995. The article in the Sun was published the day before the Channel Tunnel first opened. There was comfort to be derived from remembering Britain's insularity and Nelson's story both recalled past greatness but could be told without an imperial frame of reference. He could thus be called upon as a national icon whose presence in schools was required in defence both against non-British history and the stalking horse of Europe. Nelson, Bushell reminded his readers, had 'saved Britain from invasion' in the past. He had been mobilised by Bushell to do so again.

The presence of traditional heroes was deemed a vital corollary to the use of history to confer patriotism. Binary opposites were established: English was pitched against other, experts against subversive academics, common sense against newfangled and unpatriotic pedagogy. Insistence on a traditional canon - ranging from the medieval period (Alfred) to the modern (Churchill) is indicative of the use of the hero figure as a bookmark, threading chapters in the national story together into a coherent chronology. What is also noticeable, despite the occasional call for the teaching of empire, was the omission of pleas for the restoration of specifically imperial heroes. Despite the infrequent mention of Clive and Wolfe, there were no calls for the reintroduction of Gordon, Havelock, Napier or Roberts, for instance, all of whom featured in the curricula of 'traditional' history in the 1950s. One might argue that this was a matter of expediency: to bemoan the teaching of Indian and African history but insist on the teaching of those past characters whose histories were so bound up with the colonies would be an obvious contradiction. More likely, as I seek to demonstrate in Section IV, imperial heroes were not compatible with a curriculum which sought to promote national pride. Inserting imperial heroes into debates would force acknowledgement of the inglorious deeds of those who were once remembered as heroes of conquest, but were easily forgotten in a postcolonial context. ${ }^{59}$ Similar explanations can be given for the absence of explorers and missionaries: Livingstone is infrequently cited as a 
hero for compulsory inclusion in the curriculum; there is no mention between 1989 and 1995 of others such as Burnaby, Burton, Baker, Stanley, Irvine, or Mallory.

Anthony D. Smith has argued that politicians justify control over official national history by constructing myths of a golden age of history, a history made up of stories of heroism and connected together in a clear narrative of national progress over time. The articulation of a golden age - or the retreat to the traditional, Smith continues, requires myths of decline, or crisis, in which the work of 'enemies' is shown to have divorced the present from the past and thus creating present-day anxieties of identity. To 'fix' crises of identity, politicians can present themselves as saviours by proposing a return to past practice ${ }^{60}$ It is quite clear that critics of reforms to history teaching manufactured a golden age not only to identify progressive educationists as folk devils but to position themselves as beacons of national pride. Heroes were deployed as footsoldiers in their campaign. The press was clearly engaged in what Mike Wallace called a 'discourse of derision'. ${ }^{61}$ Such a discourse positioned proponents of 'new' history as antipathetic to national needs; traditionalists and 'traditional' history as patriotic. Experts, such as McGovern and Tate, were lauded as the voice of common sense; those who opposed them as precariously insurrectionist. In a particularly hostile article, the Express sought to expose the 'trendy... militants' behind the new history, describing them as 'leftist, fervently anti-patriotic and prone to fads' (23 March 1990). ${ }^{62}$ Professor David Carter of the Department of Philosophy, University of Durham, added his condemnation: new history promoted 'flaccid relativism about knowledge, truth and value' conferred by the 'misguided', 'fanatical', and 'multiculturalist' ideology of the left. ${ }^{63}$ Demand for English history and English heroes was presented as simple and natural; the teaching of non-British history as illogical and dangerous. The invocation of crisis, in particular, was used to explain social ills; in this instance, the teaching of British history and inclusion of a careful selection of traditional heroes was presented as a straightforward, sensible, remedy. ${ }^{64}$ 
Jonathan Clark, lecturer in history at Oxford at the time, lent his support to the New Right. In 1990, in a debate on 'History, the Nation and the Schools' held at Ruskin College, ${ }^{65}$ he argued that this desire to return to a halcyon age of history teaching was owed to a modern crisis of British national identity demonstrating nostalgia for a time "when "we" were more like "ourselves", ${ }^{66}$ The restoration of a golden age of history teaching would, in Clark's summation, rescue children from the condescension of 'post-liberal', 'post-imperial' and 'postmodern' approaches to history education: in doing so, the aim was that this would return to them a simple and politically expedient historical knowledge-base out of which to understand their nation and their place within it. ${ }^{67}$ 'Patriotism', for Clark, was more 'than a series of sentimental anecdotes of Drake, Nelson or the Battle of Britain ... [it] is essentially the idea that "we” are related to “our” history by something more than contingency'. Nonetheless, heroes mattered since they could 'evoke' patriotism. ${ }^{68}$ Anxieties of Englishness, then, were to be overcome by the implementation of the traditional as the official NC for history. Heroes, in the context of cultural restorationism, took on a significant role in the use of history to confer an unproblematic national identity. In lauding the value of national heroes by drawing derogatory contrast to 'politically correct' alternatives, media representations depicted a need for single national story which clearly excluded 'racial' others from a place within the national narrative.

In his analysis of the relationship between the media and the discursive construction of the nation in newsprint, Michael Billig draws attention to the use of language - especially the frequency of words such as 'our' and 'we' - to connote national belonging. Billig's argument that "national histories tell of a people passing through time - "our” people, with “our” ways of life, and "our” culture ... mobilised to tell the tale of "our” uniqueness and "our” common fate' - demonstrates that for the past to be 'usable', in a political sense, public consumption of the past needs be controlled through the discursive creation of a single, official, history. ${ }^{69}$ Against a backdrop of (what was perceived to be an) increasing childhood fascination with historical films, period dramas, documentaries, museums, theme parks and computer games, ${ }^{70}$ the 'official' history - in the shape of a national curriculum - was to be 
the single, definitive, account by which competing histories could be understood. The attempt to claim national heroes as instruments of official policy was deemed especially important since research had highlighted most children cited sports and musical celebrities as the individuals from whom they gained most inspiration. ${ }^{71}$ An official history was compelled, in Robert Phillips' words, to 'respond to the political-public consumption of the past' ${ }^{72}$

The addition of 'other' histories by the SHP, including the insertion of new hero figures into the curriculum, clearly threatened Conservative notions of nationhood. Roger Scruton's theorisation of the relationship between 'culture' and the 'nation' played a significant part in the shaping of the New Right's demonising of new history. Scruton wrote that conservative philosophy should prioritise the nation over individual autonomy because society stemmed from a shared community inheritance in nationhood. He believed in a common, natural and unifying culture that was unique to the British nation as a cultural as well as a political 'unit'. Only those who had this 'inner knowledge', derived from partaking in the nation's customs, habits and traditions, could understand and appreciate the 'nation'. Nationhood was thus derived from a common, inherited past. ${ }^{73}$ Scruton, writing in 1986 in opposition to world history modules, elaborated upon his thinking about the role of history in schools:

The first concern of the history teacher must be to teach the history of Britain, so that a child may understand the past in terms of its present and observable residue ... [that allows the child] ... that informed awareness of history as a living process, a form of communication with the past and the future, which stems from an awareness of the "pastness" of everything one touches, and of the evolving nature of existing social and political arrangements. ${ }^{74}$

This view, Scruton explained, developed from the core tenets of conservative conceptions of nationhood first articulated by Edmund Burke at the time of the French Revolution: each generation received a set of values and traditions, 'virtues', from their forbears that it was 
their duty to pass to the next. In this context, inherited wisdom was to be gained by an adherence to the reception of past principles. According to this philosophy, individuals existed as part of a society; for the maintenance of a stable state, social continuity had to be defended. ${ }^{75}$ Deeply embedded in this continuity was a reverence for the customs, habits and traditions of the nation. History in schools should enable the transmission of those values core to the Conservative interpretation of nationhood. Heroes would be the conduit of true English values. To appreciate those values, the hero must be situated in sequential context. The introduction of other heroes threatened the transfer of essentialist common culture. Thus 'new' history was denigrated on the grounds that it rubbished the best of tradition and threatened to destroy national identity by dislocating present children from their collective past. Traditional history, in Deuchar's words, was to be credited for focusing on a 'core' of British history because this gave the child 'breadth of knowledge and respect for the past, even a sense of gratitude towards those people from whom we have deservedly inherited this amazing civilisation ... and come to some understanding of our institutions, traditions and values' ${ }^{76}$ Traditional history and new history, simply put, were incompatible.

New history's emphasis on interpretation and enquiry thus challenged the essence of historical certainty; on some interpretations, it embodied the academic trend in the 1980s towards postmodernism. To teach children that the past was a contested space, that there were histories as well as one capital ' $\mathrm{H}$ ' history, undermined the role of shared history in identity formation. Yet to question the value of historical knowledge itself, on which conservative conceptions of nationhood were grounded, was to further degrade the usability of history. This would explain Carter's comment on 'flaccid relativism'; ${ }^{77}$ it, too, explains the necessity to use the NC to teach universal facts through a single narrative history. This perspective was playfully sent up by Keith Jenkins and Peter Brickley in an essay for Teaching History:

What Thatcherism would have liked for history was an interpretation we might call certaintist. Such a reading would confidently construct for Britain (especially 
England) a unique and pioneering historical journey from which traditional (natural) values, liberties and freedoms have evolved ... together with invocations of overriding solidarities: the people, the nation, patriotism, in order to curb any excesses such notions as liberty and freedom may suggest. Cautious, empirical in its mode of enquiry; factual and knowledge led; anti-intellectual in its distrust of theories so British history would act as the privileged centre and yardstick around which all other histories would revolve and be judged. Champion of free trade, Thatcher would close down the market-place of competing historical commodities (interpretations) erecting just one stall from which everyone would purchase authorised historical products all stamped with the legend 'Made in Britain' or, better still, 'Made in England'. ${ }^{78}$

New Right and Conservative politicians thus not only took umbrage at what was perceived to be a leftist attack on history specifically, but also - following the interventions of Jenkins and others - identified an assault on historical knowledge. Clark wondered that 'if all knowledge is relative then why not teach the perspective on the past that "we" value the most?"79

But what of the advocates of leftist and postmodern history writing? Jenkins' article, published in the same year as his provocative Rethinking History (1991) sought to valorise methods that encouraged critical enquiry and empathy. His wish was that children should recognise that knowledge was relative to the context of its production: hence, he identified in the NC a series of 'unintended opportunities'. Left-wing politicians were quick to berate Thatcher's intentions but did not object, necessarily, to the idea of a national curriculum and the inclusion of national heroes. We heard from Jack Straw earlier: as Shadow Secretary of State for education, he worried about jingoistic ambitions but to this it needs to be added that he suggested his own heroes ranging from the Tolpuddle Martyrs to the founders of the Labour movement. ${ }^{80}$ Christopher Hill, in 1989, argued that he would not mind more teaching of national history, so long as 'it recreated a more truthful patriotic history. If we just go back to national self-glorification, to painting the map red, history will be in danger of becoming a plaything of party politics, to be changed with a change of government. A little self- 
examination is in order' (Guardian, 29 May 1989). For the Mail, Roy Hattersley - a stalwart of the Labour Party in the 1970s and '80s but recently retired as an MP - wrote an article entitled 'Deny a nation its heroes and you take away its identity'. Hattersley did not object to heroes. For him, they were central to national identity and cultural homogeneity. However, along with Nelson (and Shakespeare and cricketers), Hattersley wanted the inclusion of Suffragettes, Chartists and other peoples' heroes: Ghandi and Lincoln in particular, as well as contemporaries such as Mandela and Gorbachev (19 September 1995). For Hattersley, it was a disaster that 'heroes have been obliterated from the history books ... History lessons should be in Technicolour. Without heroes, there can only be shades of grey. For it is the heroes who make the past an adventure story’.

The function of heroes as popular, not just for their deeds but for their ability to enliven accounts of the past was a view near unanimously put forward by the Left. History was a means to inspire a mass audience. Raphael Samuel was the most active left-wing historian involved with the NC debates, itself indicative of a separation between universities and schools and his realisation of the need to combat 'the Right at their own game' ${ }^{81}$ Samuel, cautious about an overt politicisation of the curriculum, nonetheless thought the new history's concentration on the local, the critical and the procedural had damaged history's 'popular (and classroom) appeal’. For Samuel, the absence of “"Drum and Trumpet” History, or history 'as the biography of great men' had meant school history had lost its 'subversive potential' to teach alternative narratives of British history. How else, asked Samuel (in a question at the heart of this special issue), could the 'sadly neglected' history of the empire be subjected to critique without teaching children 'those sensational occurrences, extreme situations and memorable characters’? (Guardian, 23 September 1995). Moreover, in Samuel's opinion, asking why Mary Seacole could be forgotten by posterity - but Nightingale remembered - would expose processes of cultural memory. ${ }^{82}$ Nor did Samuel have any qualms about the inclusion of Nelson. In an article for the Independent, with the evocative title 'Heroes Beneath the Hooves of History’ (31 August 1989), Samuel posed the question: without knowing who Nelson was, how were children to understand the historical 
context in which Nelson was made and retained as the prime British hero? (Guardian, 23 September 1995). Imperial history, too tricky to teach in too much detail, had become sidelined in NC debates and sidestepped by New Right critics. Samuel, however, was not afraid to suggest the teaching of imperial heroes. His concentration on Nelson was intended to explain how the nineteenth-century imperial context, especially the glorification of war, accounted for Nelson's heroic reputation. Samuel also included Gordon and Milner as examples of characters who could be studied to explore the late-Victorian relationship between religion and empire. ${ }^{83}$ What Samuel's contribution, and those of Hattersley and Straw denote, is the awareness of the usability of national history - and its heroes - in forging a particular narrative depiction of the nation and its identity.

The issue, then, was whose narrative of national history should be used? Clearly, this was an historiographical problem; but one which, in the context of NC debates, had become acutely political. That single, usable, and certaintist history around which the New Right wished to form an official curriculum was unachievable. Their insistence on such a curriculum, despite reinforcement by the press, provoked debate about competing national narratives and thus exposed history as essentially contested. These debates, too, also exposed national identity itself as fluid and subject to political control. For some New Right critics, heroes were deployed in battle against those who threatened their idealised and usable curriculum: whether that was Namibian women, the Beninese or Aztecs; or - indeed - leftwing academics and educational theorists who sought to subvert 'our' cultural heritage. Deuchar was able to denigrate 'new' history as a 'manifestation of our postcolonial neuroses'; yet in admitting of neurosis acknowledged an obsession with a past that was not uniformly glorious. ${ }^{84}$ Samuel was correct: debate about how to teach the empire was largely absent in the media, even though papers had clearly articulated a version of 'English' identity which was defined against others who would be the subject of world history modules. These debates, about the relationship between history teaching and national identity, were conducted largely without reference to the imperial past. This would explain why no New 
Right critic would request the compulsory teaching of a General Gordon or a Havelock, but those on the political left could.

Thus, debates about the teaching of history in general and the role of heroes in particular reveal particular insights into the ambiguities of post-imperial identity. The rise of constituent nationalisms in the 1970s and '80s certainly reflected and, perhaps, fed subsequently from four-nations historiography. ${ }^{85}$ Scotland, Wales and Ireland not only developed and revived national histories in the 1980s and '90s but found their heroes - and often these were individuals made heroic for their struggles against the English: Wallace, Bruce, Owain Glyndŵr, Llewelyn ap Gruffudd. It was not so easy for the English to call on such heroes. Nelson and Churchill certainly fulfilled the role of defending the homeland; yet those imperial heroes of the traditional canon had been made heroic in the past as part of the imperial project. Imperial heroes, in the context of the late-twentieth century, were too divisive to be included in what - if the New Right had their way - would be a fact-led official document of English history. ${ }^{86}$ If the argument that the New Right avoided certain heroes because they were reluctant to address problematic questions of race and imperial memory is persuasive, then this view takes on particular significance in responses to the Parekh Report. The question of race came to the fore in debates about how history - again an official history in recommendations for curriculum amendment - was intended to express nation and identity.

\section{IV - Confronting the imperial past}

The Runnymede Trust was convened, by Jack Straw - by 2000, Home Secretary under a Labour administration - in order to develop policies for the harmonisation of race relations. Amongst other recommendations, the Report, The Future of Multi-Ethnic Britain (published October 2000), concluded that the 'national story need[ed] rewriting' ${ }^{87}$ In response to research suggesting the dominance of metropolitan English history in the teaching of British history was in part the cause of modern confusions about Britishness, the Trust proposed to rebrand 'British' as a 'community of communities' rather than a single ethnic entity united 
through shared history. This was proposed not only in order to make the curriculum more relevant for the children of ethnic minorities, but children from Ireland, Scotland, Wales and the regions too. Journalists were rapid in their condemnation of what was perceived to be an official directive to 'jettison' aspects of 'traditional' history since, in their understanding, the Trust's recommendation constituted an institutional abrogation of Britishness. Richard Littlejohn, then of the Sun, fumed that 'if the recommendations of the Report were to be implemented, children will be told stories and lies about their history and encouraged to feel ashamed of their country’ (13 October 2000).

The Report's author, Bhikhu, Lord Parekh, argued that '[t]he absence from the national curriculum of a rewritten history of Britain as an imperial force involving dominance in Ireland as well as Africa, the Caribbean and Asia, is proving from this perspective to be an unmitigated disaster'. ${ }^{88}$ Recognising that 'Britishness, as much as Englishness, has systematic, largely unspoken, racial connotations’ (38-9), Parekh explained:

Britain confronts a historic choice as to its future direction. Will it try to turn the clock back, digging in, defending old values and ancient hierarchies, relying on a narrow English-dominated backward-looking definition of the nation? Or will it seize the opportunity to create a more flexible, inclusive, cosmopolitan image of itself? Britain is at a turning point. But it has not yet turned the corner ... What does Britain stand for? Of what may citizens be justly proud? How has the imagined nation stood the test of time? What should be preserved, what jettisoned, what revised or reworked? How can everyone have a recognised place within the larger picture? These are questions about Britain as an imagined community, and about how a genuinely multicultural Britain urgently needs to reimagine itself ... expunging the traces of an imperial mentality from the national culture, particularly those that involved seeing the white British as a superior race ... This mentality penetrated everyday life, popular culture and consciousness. It remains active in projected fantasies and fears about difference, and in racialised stereotypes of otherness. The unstated assumption 
remains that Britishness and whiteness go together, like roast beef and Yorkshire pudding ... The absence from the national curriculum of a rewritten history of Britain as an imperial force, involving dominance in Ireland as well as Africa, the Caribbean and Asia, is proving from this perspective to be an unmitigated disaster. ${ }^{89}$

The extract from the Parekh Report is reproduced at length for three reasons. First, given that the architects of the NC had been condemned for their lack of patriotism because they had included insufficient English history, the uniformly barbed press responses to the Report indicate a continuity of practice a decade later: those who would challenge the core of national history would be attacked for denigrating British culture and identity. According to the Mail, the Report was a 'brainwashing exercise designed to destroy our sense of nationhood' (11 October 2000). The Telegraph headline was entitled 'Thinkers who want to consign our island story to history' (note the recurrence of that phrase 'consign to history'). The article continued:

A think-tank called the Runnymede Trust will publish a major report tomorrow about Britain's multi-ethnic future. It says millions of contemporary British have been left out of a story that is "England-centred and, indeed, southern England-centred" ... "Englishness is in the process of being redefined", says the report, The Future of Multi-Ethnic Britain, and the nation's very history should be rethought and certain aspects “jettisoned, revised or reworked”. It wants Britain formally to declare itself a “multi-cultural society”' (10 October 2000).

As with NC debates, the press identified an assault on the integrity of Britishness itself through suggestions that national history needed consigned to the past.

Second, the media response illustrates the discourse of derision in continued operation: although the Report was careful to differentiate between the terms 'racial' (a legal designation) and 'racist', newspapers highlighted alarm at the suggestion that there was 
shame in the past. The Star (12 October 2000) described the Report as 'the latest example of political correctness gone mad', incredulous at the suggestion - based on the Telegraph misreporting - that 'it is now racist to be British'. On the same day, the Sun, in alarmist fashion, summarised the Report's objectives: we should 'feel ashamed of our history and apologise'. ${ }^{90}$ Concern was all the more acute since the Report had been convened at the behest of the then Home Secretary, Jack Straw, and was thus understood to be an attempt to put into a place an alternative official, institutional, narrative of British history. In the face of hostile media reporting, Straw was compelled to distance himself, declaring himself 'proud to be English and proud to be British' and 'proud ... of the best of British values' (The Times, 11 October 2000).

Third, responses to the Report both exposed post-imperial identity confusion but also suggested the possible wedding of new formulae of Britishness which could take root from old histories. Parekh had proposed to teach a history of the present which would require an official declaration that British imperial history had bequeathed a problematic legacy for modern Britain. In drawing explicit attention to the deleterious impact of imperial history on modern social and racial cohesion, the Report forced the Right to confront those questions they had hitherto set to one side. Although it was straightforward for the press to denigrate the report and deride its proposal for future identity formation - around a 'community of communities' - debate, nonetheless, generated fascinating acknowledgements that British history itself had been composed of centuries of immigration. As a result, Fortier finds a number of letters written to the newspapers in which immigrants (or their descendants) queued up to declare their pride in being 'British'. ${ }^{91}$ The Report had attempted to formulate models of Britishness which not only accounted for the past exercise of imperial power, but sought to use debate as the framework for new modes of civic belonging. However, in doing so, the Report had forced acknowledgement that there was not a single, uncontested, narrative of the national past, but several; that modern Britain was made up of multiple histories and multiple identities, forged as a result both of centuries of immigration and migration and empire building and decolonisation. 
Abby Waldman explains that 'post-war immigration had led in Britain to an official recognition of communities which cherished multiple identities and loyalties'. ${ }^{92}$ New history, the context of the 1970s and '80s, had sought to introduce students to non-British perspectives on the relationship between history and the unfolding of the modern world. Thus, the Schools Council conceived of modules charting Asian and African history which included opportunities to study histories of immigration and settlement. This explains why Mary Seacole and Olaudah Equiano became regularly taught; it also explains why the complicated, divisive histories of characters such as Gordon and Havelock remained largely ignored in these curriculum debates, as they had been since the 1970s. New history, in Waldman's words, was ‘a natural ally of pluralism'. ${ }^{93}$ In terms of analysis of how Englishness was constituted in New Right rhetoric, emphases on a single narrative of cultural heritage were also indicative of a monolithic notion of nationhood. The incompatibility of new and traditional history, then, is made clearer in the context of these later discussions of race evident in response to the Parekh Report. Likewise, calls for the reinstatement of some heroes, but not others, are suggestive of what Paul Gilroy labels 'postcolonial melancholia'. For Gilroy, the Empire could be ‘actively forgotten’ and memories of imperial atrocities 'repressed': national identity, drawn from history, could be forged through the duality of a deliberate detachment from the imperial past that still allowed taking comfort in selected historical moments. ${ }^{94}$ In this context, those pleas in the 1980s and '90s for the compulsory teaching of Nelson, Henry VIII, Nightingale, and so on, can be understood as the search for a usable history - one that not only uses heroes as links in the chain of continuous national history, but also identifies heroes which articulate national values without forcing confrontation with the imperial past.

The Parekh Report thus provoked acknowledgement about the relationship between the imperial past, the teaching of history and national identity. The absence of imperial heroes in a prescribed pantheon of Englishness testifies to ongoing ambiguities of identity: imperial memory remains too controversial to teach in schools. It is not possible to argue the 
Report was successful in its ambition. The Trust reported several newspapers to the Press Complaints Commission and was disowned by Straw. The Report, however, acknowledged that identity might derive from presentist civic ties as well as historical relationships.

Although it is only speculative to draw a line between the Report and subsequent amendments to education policy, and one need also to take into account that New Labour had a different vision of a NC for history, there have been some intriguing developments.

Statutory lessons in Citizenship were introduced in 2002. A popular textbook in schools, first published in 2008, not only teaches imperial history as a series of global relationships, rather than English imposition, but encourages children to ask questions about why certain characters - including Clive of India - became 'heroic'. ${ }^{95}$ Neither development met with any animus in the press. This is surprising given that the textbook was produced by the SHP and deployed a range of pedagogical techniques encouraging children to question grand narratives. Moreover, citizenship lessons were conceived, following Linda Colley’s advice in her Millennium Lecture in which she urged politicians to 'think hard about the distinction between identity and citizenship and focus on the latter'. 'Identity', for Colley, was no longer the glue that bound people together into a collective national unit; it was too 'ancestral and visceral'. Instead, she promoted citizenship because it was both 'political and functional' and could educate 'all of the inhabitants of these islands that they are equal and valued citizens irrespective of whatever identity they may individually select to prioritize'. ${ }^{96}$ Under New Labour's watch, the essential necessity of history as the chief ingredient of collective identity was superseded by the need to teach attachment to civic state. ${ }^{97}$

\section{Conclusion}

This essay has sought to investigate debates about NC history in order to interrogate the notion that contestation about the content and teaching methods of history reveals anxieties of post-imperial identity. It is clear that the NC was intended to restore an unproblematic narrative of national history which, including the teaching of heroes, would - by design ameliorate late twentieth-century identity confusion. Yet the teaching of history is neither 
straightforward, nor is the concept of identity. Identity is an elusive, slippery, and highlycharged political concept. It is not a monolithic entity and attempts to construct identity through the teaching of a single story of the past, played out in stories of keynote individuals, prompt as much perplexity as they do certainty. If anything, these debates reveal that anxieties about the place of imperial history and 'imperial' heroes in the curriculum not only compounded confusion, but demonstrate debates are more indicative of present-day concerns. The teaching of imperial heroes was contingent upon their modern-day utility. As established in the introduction to this issue, heroes are culturally constructed in the image of the period that requires them. Nelson was usable, others were not.

Englishness was and remains at a crossroads, caught between a nostalgic sense of its glorious past and a future which that past had not predicted. Moreover, appeals to a common history may have aimed to ameliorate crises of identity, but, in seeking to reinstate traditional English heroes, NC debates also reveal ongoing tensions about definitions of post-imperial identity. In facing the future, it appears that collectively confronting that imperial past remains a contentious, yet necessary, part of the process of national redefinition.

\section{Notes.}

${ }^{1}$ For an overview of the history of history teaching, see Cannadine, Keating and Sheldon, Right Kind of History. Eric Evans traces the history of how the Victorian period was taught across the twentieth century: 'Victorians at School'. For closer analysis of the role of the state in the development of history teaching in schools before the Second World War, see my Citizenship, Nation, Empire (forthcoming).

${ }^{2}$ This brings to mind Frank Füredi's observation that there no longer 'a history with a capital $\mathrm{H}$; there are many competing histories', Mythical Past, 8.

${ }^{3}$ It is no exaggeration to suggest that NC debates provoked questions about culture and identity in the UK in the same way that debate about the National History Standards was to unleash furious debate in the United States. See Nash, Crabtree and Dunn, History on Trial. For international perspectives, see Foster and Keith Crawford, eds. What Shall We Tell the Children?

${ }^{4}$ Phillips, Goalen, McCully and Wood, 'Four Histories', 153. See also McKiernan, 'History in a National Curriculum'.

${ }^{5}$ Robert Phillips expertly traces debates about the 'making' of the NC in his History Teaching, though his work contains very little comment on teaching the imperial past or the contested role of heroes. For more on the NC debates, see, also, McCulloch, 'Privatising the Past'; Crawford, 'History of the Right'; and Little, 'National Curriculum for History'. Abby 
Waldman's recent intervention is of interest to this special issue given she contrasts Britain's curriculum debates with those in France, 'Politics of History Teaching'.

${ }^{6}$ I use 'English' very deliberately here. Scotland would retain its own education system.

Statutory orders would apply to Wales, but as is clear in a number of studies, NC debates provoked such severe discussion since they largely related to English history and the politics of English identity. Seminal texts on 'four nations historiography' were cited in the responses of educationists: see, for instance, Phillips, et al, 'Four Histories'. For Welsh perspectives, see Jones, 'Debate over the National Curriculum'.

${ }^{7}$ See for example, Letwin, Anatomy of Thatcherism; Lawton, Tory Mind on Education.

${ }^{8}$ See for instance, Turner, ed. State and the School.

${ }^{9}$ Slater, Teaching History; Van der Leeuw-Roord (ed.) State of History Education.

${ }^{10}$ de Groot, Empire and History Writing; Mandler, History and National Life. Mandler has contributed much to the debate in recent years through public engagements and blogging. See, for instance, 'Is History in Danger?'

${ }^{11}$ There are a few exceptions, though contributions tend either to be short opinion pieces or cover a long chronology: Harnett, 'Heroes and Heroines'; Sherwood, 'Race, Empire and Education'; Visram, ‘British History: whose History?; Marks, 'History, the Nation and Empire', 111-9.

${ }^{12}$ Cannadine, et al., Right Kind of History, 16-17.

${ }^{13}$ A view explored, and contested, by Howe, 'Internal Decolonisation?'

${ }^{14}$ Fortier, 'Pride Politics', 563.

${ }^{15}$ Runnymede Trust, Future of Multi-Ethnic Britain, 25.

${ }^{16}$ Research funded under the ESRC Devolution and Constitutional Change programme, Award No. L219-205-2035. The project, on which I worked as an ad hoc researcher, sought to investigate public history through three research angles: historiography, heritage and the media. Unfortunately, following the untimely death of Professor Phillips, the project was unable to fulfil all of its original objectives. The project database I compiled charted newspaper coverage identifying key dates. A volume containing short essays on historiography was published in 2004: Brocklehurst and Phillips, eds, History, Nationhood and the Question of Britain, including a short scoping essay which made brief use of newspaper research: Brocklehurst and Phillips, "“You're History”. A special issue of the International Journal of Historical Learning, Teaching and Research 3:1 (2003) was given over the topic of history in schools.

17 Aldrich, 'New History', 210-24.

${ }^{18}$ Price, 'History in Danger', 342-347.

${ }^{19}$ Robbins, 'History'.

20 Jones and Ward (eds.), New History.

${ }^{21}$ SCHP, New Look.

${ }^{22}$ see my 'A "Golden Age” of history teaching? A long view on pedagogies of citizenship and identity', paper delivered at the 'Educating the Nation[s]: history, identity and citizenship' conference, Huddersfield, July 2013. Papers are being expanded for a special issue of the History Workshop Journal (forthcoming).

${ }^{23}$ Schemilt, 'Beauty and the Philosopher'; Phillips, History Teaching, 17-24. As I demonstrate in my forthcoming book, many of these pedagogical approaches were not altogether new, borrowing from the techniques used to teach younger children from the turn of the twentieth century. See Chapter Two of Yeandle, Citizenship, Nation, Empire, 'The Renaissance of the Child? Educational Theory and the Teaching of History'.

${ }^{24}$ On teaching methodology, see Baldwin's fascinating essay, 'In the Heart or in the Margins', 130-144. 
${ }^{25}$ By 1989, for instance, only a quarter of schools used SHP syllabi at GCSE (the first GCSE exams were sat in 1988). Even when its syllabi were not taken up, SHP resources, including worksheets - photocopiers came of age as a resource for teachers in the 1980s - and textbooks, were popular in a large number of secondary schools. Phillips, History Teaching, 20; See also Marsden, School Textbook, 63.

${ }^{26}$ Dennis Gunning made clear in 1978: 'There is an academic discipline called 'History'. There is also a school subject called 'History'. There is no self-evident reason why they have to do the same. If we are teaching fourteen-year-olds, we should subject everything we teach them, whether a fact, a concept, or a skill to this question: "Of what use, or potential use, is this knowledge to them”'? Gunning, Teaching of History, 14.

${ }^{27}$ Slater, 'History and Controversy'.

${ }^{28}$ Ballard, ed. New Movements, 5.

29 This is Shula Marks' phrase, 'History, the Nation, and Empire', 112.

${ }^{30}$ See Osler, 'Still Hidden'; Visram, 'British History, Whose History?'

${ }^{31}$ Strong, History in the Secondary School, 49.

${ }^{32}$ Cited by Syriatou, 'Educational Policy and Educational Content', 47.

${ }^{33}$ Slater, Politics of History Teaching, 1

${ }^{34}$ SCHP, New Look, 19-20, 42.

35 There were many of these; the titles of some anticipate the use of militaristic language in curriculum debates: Cox and Dyson, eds. Fight for Education; Cox and Dyson, eds. Black Paper Two; Cox and Boyson, eds. Black Paper 1975.

${ }^{36}$ On the history of the New Right and its relationship to education policy, see Quicke, 'The "New Right”; Chitty, Towards a New Education System; Jones, Right Turn; Knight, Making of Tory Education Policy.

${ }^{37}$ See Gamble, Free Economy; Evans, Thatcher.

${ }^{38}$ Gamble, Free Economy, 28. See also Whitty, 'New Right and the National Curriculum'.

${ }^{39}$ Although Thatcher was discussing history teaching in particular, her views on the negative impact of the left's historical self-understanding is clear. Thatcher, 'Speech to the

Conservative Party conference'. On Thatcher's attitude to history more generally, see Samuel, 'Mrs Thatcher’s Return', 9-29; Porter, ““Though Not a Historian Myself...,” 246-56.

${ }^{40}$ Deuchar, New History, 5.

${ }^{41}$ Partington, 'History: Rewritten', 69-70.

${ }^{42}$ Crawford, ‘A History of the Right'; Cunningham, 'Teachers’ Professionalism'; see also Wallace, 'Discourse of Derision'.

${ }^{43}$ On the move towards 'world history', see the little-known essay by Samuel, published posthumously in 2003. 'A Case for National History?' Simon Joyce implies the London riots of 1981 redoubled attention to education policy, confirming the need for a return to Victorian discipline. Joyce, Victorians in the Rearview Mirror, 121.

${ }^{44}$ Kedourie, Errors, 14.

${ }^{45}$ Kedourie, Errors, 12.

${ }^{46}$ Cited in Visram, 'British History, Whose History', 54-5.

${ }^{47}$ Samuel, 'History, the Nation and the Schools', 78.

${ }^{48}$ These are Robert Guyver's words. Guyver, a specialist in Primary School History, was one of the members of the HWG. Guyver, 'History's Domesday Book', 86.

${ }^{49}$ In particular, see responses to Kenneth Clarke's decision as Secretary of State for Education against making History compulsory at GCSE. Phillips, History Teaching, 105-8. See also Mandler's generous account of Clarke's predecessor, Keith Joseph, who was careful to define the difference between a 'national' and a 'nationalistic' curriculum - much 
preferring the former and holding the latter, unlike some of the New Right, in bad taste. Mandler, History and National Life, 128.

${ }^{50}$ Parliamentary Debates (Hansard): House of Commons Official Report, 14 November 1989, col. 172.

${ }^{51}$ Hall, Hard Road to Renewal.

52 Thatcher, Downing Street Years, 590. Dimitri Coryton, former Chairman of the

Conservative Education Association, bemoaned the accuracy of Thatcher's recall, claiming that in her mind 'the expert is dismissed as a vested interest so the inexpert ideologue had the field', see Ball, Politics and Policy Making, 48.

53 Thatcher, Downing Street Years, 595-6; Waldman, 'Politics of History Teaching', 204.

${ }^{54}$ Parliamentary Debates (Hansard): House of Commons Official Report, 29 March 1990, col. 668.

${ }^{55}$ McGovern, SCAA Review. SCAA is the acronym for the Schools Curriculum and

Assessment Authority.

${ }^{56}$ For discussion, see Phillips, 'Thesis and Antithesis', 30-3.

${ }^{57}$ N. Tate, 'Role of History'.

${ }^{58}$ For discussion, see Samuel's measured response 'The People with Stars in their Eyes'

(Guardian 23 September 1995). See also Phillips, 'Thesis and Antithesis'; Jones and Watkins' Necessary Fantasy, introduction.

${ }^{59}$ Similar debate surfaced in 2000 in relation to statuary in Trafalgar Square, in which shock was depicted that most Britons were unable to identify Havelock or Napier's contributions to British history. See Cherry, 'Statues in the Square'; Schwarz, "'Strolling Spectators”'.

${ }^{60}$ Smith, Myths and Memories, 64-8.

${ }^{61}$ Wallace, 'Discourse of Derision'; Ball, Politics and Policy Making, 3-19.

${ }^{62}$ See also Ball 'Education, Majorism’, 195-214.

${ }^{63}$ Cited from in Phillips, History Teaching, 45.

${ }^{64}$ On this, see Quicke, 'The "New Right”, 5-20.

${ }^{65}$ Some of the papers of which are reproduced as a special feature in History Workshop Journal, 29 (1990), 92-133, including short articles by Clark, Raphael Samuel, Janet Nelson, Alice Prochaska and Sylvia Collicott.

${ }^{66}$ Clark, 'National Identity', 101.

${ }^{67}$ Clark, 'National Identity', 96.

${ }^{68}$ Clark, 'National Identity', 100.

${ }^{69}$ Billig, Banal Nationalism, 71.

${ }^{70}$ See de Groot, 'Empathy and Enfranchisement', 391-413.

${ }^{71}$ Explored in Goalen, 'The History Curriculum', 23-32.

${ }^{72}$ Phillips, 'Contesting the Past', 43.

${ }^{73}$ Scruton, Meaning of Conservatism, 180-189.

${ }^{74}$ Scruton, 'Myth of Cultural Relativism', 134-5.

${ }^{75}$ Beck, 'Nation, Curriculum and Identity'.

${ }^{76}$ Deuchar, New History, p.3.

${ }^{77}$ Carter's language brings to mind the gendered and sexualised language used in identity

debates which Max Jones addresses in his essay.

78 Jenkins and Brickley, ““Always Historicise”...', 12.

${ }^{79}$ Clark, 'National Identity', 101.

${ }^{80}$ Samuel, 'History, the Nations and the Schools', 75.

${ }^{81}$ Phillips, History Teaching, 131-2.

${ }^{82}$ Samuel, 'History, the Nations and the Schools', 78-9.

${ }^{83}$ Samuel, Island Stories, 297-8. 
${ }^{84}$ S. Deuchar, 'Letter', Times Educational Supplement, (29 January 1988), cited in Phillips, History Teaching, 43.

${ }^{85}$ See, for instance, the mobilisation of Rees Davies’ and Gwyn Williams’ work on Wales, and David McCrone's and Tom Devine's work on Scotland by Plaid Cymru and the Scottish National Party. Davies, First English Empire; Williams, When Was Wales?; Devine, Scottish Nation; McCrone, Understanding Scotland.

${ }^{86}$ This brings to mind Tom Nairn's argument, formulated in the 1970s in the context of scholarly debate about anglo-British relations. If one follows Nairn's view that devolution marked the final break-up of the British Empire, then the English - in seeking to reassert the primacy of traditional history - had sought a curriculum incompatible with its present realities. Empire, in Nairn's formulation, was the glue that bound Britain together, and without the Empire, Englishness was the 'the battered cliché-ridden hulk' left behind by 'the retreating tide of imperialism'. Nairn, Break-Up of Britain, 340.

${ }^{87}$ Future of Multi-Ethnic Britain, 25.

${ }^{88}$ Future of Multi-Ethnic Britain, 25.

${ }^{89}$ Future of Multi-Ethnic Britain, 15-16; 25.

${ }^{90}$ On these, see Richardson, "“Children Will Be Told Lies".

${ }^{91}$ Fortier, 'Pride Politics', 564-6.

92 Waldman, 'Politics of History Teaching', 213.

${ }^{93}$ Waldman, 'Politics of History Teaching', 213.

${ }^{94}$ Gilroy, After Empire, 97-8; 102; 107-8.

${ }^{95}$ Riley, Byrom and Culpin, This is History!

${ }^{96}$ Colley, 'Britishness in the $21^{\text {st }}$ Century'.

${ }^{97}$ Mycock, ‘Enduring Legacy’, 170-91. 